\title{
Polarographic Behavior of Metal Ion in Water-Organic Solvent Mixtures
}

\author{
By \\ Makoto Suzuki, Shigeo SAwAda and Kojiro Yasuda \\ (Department of Chemistry, Faculty Science and Technology, \\ Kinki University, Kowakae, Higashi-Osaka Japan) \\ (Reaeived August 25, 1971)
}

\begin{abstract}
Symopsis
In water-organic solvent mixtures, polarographic diffusion currents and halfwave potentials were measured.

It was concluded that the diffusion currents were dependent not only viscosity of the mixture, but also on the "relaxation effect" of the ion, solvation and ion-pair formation. The variation of the half-wave potential corrected for liquid junction potential referred to the half-wave potentials of ferrocene and cobalticinium ion did not obey Born's equation. This was ascribed to ion-pair formation.
\end{abstract}

\section{Introduction}

It has been known that the diffusion current and the half-wave potential of metal ion vary with changing composition of water-organic solvent mixtures. These variations were ascribed qualitatively to the variation of viscosity of the mixture, the liquid junction potential, the free energy change of ion in the mixtures, etc.

In the present investigation the above factors were examined in some detail by taking into account the "relaxation effect" of ion and by employing the potentials of ferrocene and cobaltocene systems as a standard potential.

\section{Experimentals}

Among the organic solvents used, dioxane was refluxed with sodium metal for 8 hours, acetonitrile (AN) was sufficiently dried on silica gel, and dimethylformamide (DMF) on anhydrous potassium carbonate, then, they were fractionally distilled with rectifier. For other chemicals the special grade or the corresponding grade reagents available commercially were used without further purification. The concentration of the depolarizer was $0.5 \mathrm{~m} M$. The supporting electrolyte was $0.2 M \mathrm{LiClO}_{4}$ except that for $\mathrm{Pb}(\mathrm{II})$, which was $0.1 M \mathrm{NaClO}_{4}$.

Polarographic measurements were made with a Yanagimoto Type GA-103 Galvarecorder with Yanagimoto voltage applying equipment for polarograph at $25^{\circ} \mathrm{C}$. The density and viscosity of the solution containing $0.2 M \mathrm{LiClO}_{4}$ was determined with a Weld type picnometer and with an Ostwald viscometer at $25^{\circ} \mathrm{C}$, respectively.

An aqueous staturated calomel electrode was used as a reference electrode. The characteristics of the dropping mercury electrode used were $t=5.5 \mathrm{sec}$. and $m=1.314$ $\mathrm{mg} / \mathrm{sec}$. at a pressure of $80 \mathrm{~cm}$. Hg (uncor.) on open circuit in aqueous solution con- 
taining the electrolyte. The drop time decreased approximately regularly with increasing solvent contents.

\section{Results and Discussion}

\section{On the diffusion current.}

In water-organic solvent mixture, the viscosity of the solution varies not only with nature and composition of organic solvent, but also with those of supporting electrolyte $^{1)}$. The experimentally determined variations of relative viscosity with changing composition of water-dioxane, $-\mathrm{D} \mathrm{MF}$, and $-\mathrm{AN}$ mixtures containing $\mathrm{Li}$ - or $\mathrm{Na}-\mathrm{ClO}_{4}$ as a supporting electrolyte are illustrated in Fig. 1.

It is also expected that the change of solvent composition in the mixture causes variation of the interfacial tention between solution and mercury, and hence variation of the characteristics of the dropping mercury electrode. It was experimentally found, however, that the drop time of the dropping mercury electrode was changed practically about $10 \%$ in maximum when the composition of the solution changed from pure aqueous solution to pure organic solvent and hence the effect of change in drop time on the diffusion current was less than $1.8 \%$. It was also found that the variation of solvent composition had little effect on the rate of flow of mercury. The variation of the characteristics of the dropping mercury electrode, therefore, has practically no influence on the diffusion current within experimental error and so in the present study the diffusion current was uncorrected for the variation of the characteristics of the dropping mercury electrode.

Consequently, assuming that the variation of diffusion current with changing composition of the organic solvent is only caused by viscosity change of the solution and Stokes' law is held, the product of diffusion current, $I_{d}$, and square root of viscosity of the solution, $\eta$, may be a constant in all the solutions. That is,

$$
I_{d_{0}} \cdot \eta_{o}{ }^{1 / 2}=I_{d_{a}} \cdot \eta_{a}^{1 / 2}=\text { const. }
$$

where subscrip to and a imply the values in pure aqueous solution and any water-organic solvent mixture, respectively. The relative diffusion current in any composition of aqueous organic solution referred to the diffusion current in pure aqueous solution can be calculated from equation (1) as follows,

$$
I_{d_{a}}=I_{d_{o}}\left(\eta_{0} / \eta_{a}\right)^{1 / 2} \text {. }
$$

Fig. 2-4 show the variations of the relative values observed and those calculated from the above equation with composition of the organic solvent. In the figures the value of diffusion current in pure aqueous solution is represented as unity since it is taken as a reference.

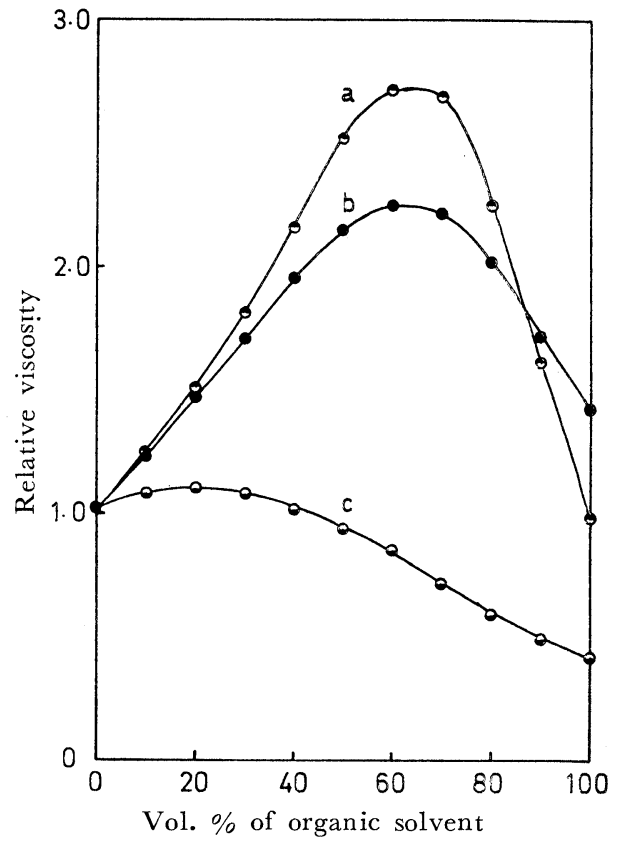

Fig. 1. Variation of relative viscosity with content of organic solvent containing supporting electrolyte

(a) DMF, (b) dioxane, (c) $\mathrm{AN}$ 


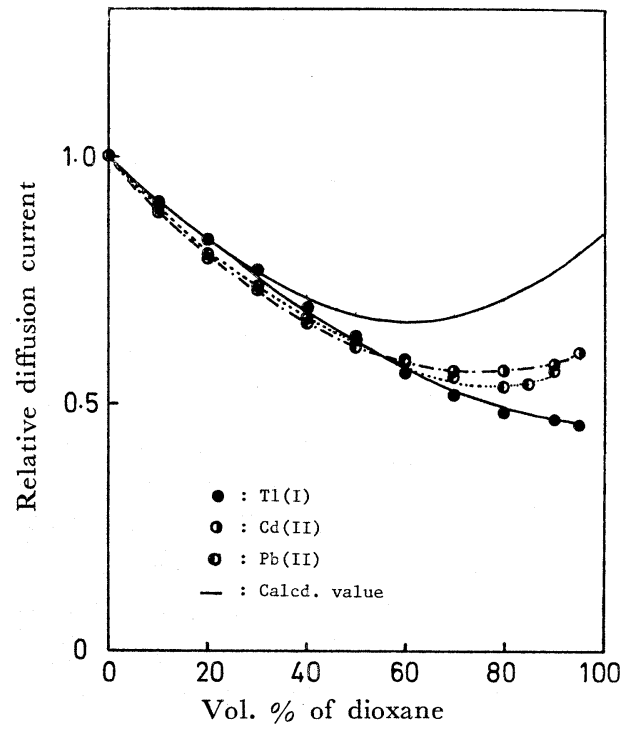

Fig. 2. Variation of diffusion current with content of dioxane

In water-dioxane system (Fig. 2), the observed values are approximately agreed with the calculated values up to about $50 \%$ of organic solvent content, independently of the nature of mental ion used as a depolarizer, but the deviation between the observed and calculated values becomes progressively larger as dioxane content increases further. The deviation for $\mathrm{Tl}$ (I) ion is particularly larger than those for $\mathrm{Pb}$ (II) and $\mathrm{Cd}$ (II) ions. In water-AN system (Fig. 3), the deviation is already marked in low AN content and those for $\mathrm{Tl}$ (I) and $\mathrm{Pb}$ (II) ion become larger with increasion AN content. But the extent of deviation for Cd (II) ion is almost not changed in the solution of 40 $\%$ to $100 \%$ AN contents. In water-DMF system (Fig. 4), the deviation for all the ions becomes larger with increasing DMF content.

The above fact that there is a deviation between the observed and calculated values suggests that some factors other than viscosity are effective on the diffusion current in water-organic solvent mixture.

According to Tachi and Takahashi"), variation of the "relaxation effect" with change in dielectric constant of the solution by changing the content of organic solvent makes a change of the diffusion coefficient of an ion. They used Robinson-Stokes equation $^{3)}$ to evaluate the diffusion coefficient in infinite dilution and derived the fol- 
lowing equation

$$
\mathrm{D}={ }^{\circ} \mathrm{D}(1-\Delta)
$$

and

$$
\begin{aligned}
& \Delta=\frac{8 \pi \mathrm{Ne}^{2}}{3 \varepsilon \kappa T}\left|z_{1} \cdot z_{2}\right| \frac{\chi}{1+a \chi} \cdot \frac{q}{1+\sqrt{ } q} \\
& q=\frac{\left|z_{1} \cdot z_{2}\right|}{\left|z_{1}\right|+\left|z_{2}\right|} \cdot \frac{{ }^{\circ} \lambda_{1}+{ }^{\circ} \lambda_{2}}{\left|z_{2}{ }^{\circ} \lambda_{1}\right|+\left|z_{1}{ }^{\circ} \lambda_{2}\right|} \\
& \chi=\left(\frac{8 \pi \mathrm{Ne}^{2}}{1000 \varepsilon K T}\right) 1 / 2 \sqrt{I} \\
& I=\frac{c}{2}\left(\left|z_{1}\right|+\left|z_{2}\right|\right)
\end{aligned}
$$

where $D$ is the diffusion coefficient of the diffusing ion, ${ }^{\circ} D$ that in infinite dilution and $\varepsilon, \kappa, T, \mathrm{~N}$ and e mean dielectric constant, Boltzmann constant, absolute temperature, Avogrdro number and an electronic charge, respectively, and a is the effective diameter of the ion which is estimated to be $4 \AA$ in general. $Z_{1}$ and $Z_{2}$ are valencies of cation and anion of the depolarizing salt, respectively and ${ }^{\circ} \lambda_{1}$ and ${ }^{\circ} \lambda_{2}$ mean the equivalent conductivities of cation and anion in infinite dilution, respectively, and $c$ is the normarity of the supporting electrolyte.

From the above equation (3) and Ilkovic equation the following relation for the diffusion current is obtained;

Table I. Comparison of Calcd. and Obsd. Values of the Diffusion Currents of $\mathrm{Tl}(\mathrm{I})$

\begin{tabular}{c|c|c|c|c}
\hline $\begin{array}{c}\text { Solvent } \% \\
\text { (in Vol.) }\end{array}$ & $\varepsilon$ & $\begin{array}{l}I_{d}(\mu \mathrm{A}) \\
\text { (Calcd. })\end{array}$ & $\begin{array}{l}I_{d}(\mu \mathrm{A}) \\
(\text { Obsd. })\end{array}$ & $\begin{array}{c}\Delta I_{d} \\
(\mu \mathrm{A})\end{array}$ \\
\hline
\end{tabular}

(A) In Water-Dioxane Mixture

\begin{tabular}{l|l|l|l|l}
\hline 0 & 78.5 & 2.28 & 2.28 & 0 \\
10 & 69.5 & 2.06 & 2.08 & -0.02 \\
20 & 61.0 & 1.89 & 1.90 & -0.01 \\
30 & 52.0 & 1.71 & 1.77 & -0.06 \\
40 & 44.0 & 1.57 & 1.59 & -0.02 \\
50 & 35.5 & 1.47 & 1.45 & +0.02 \\
60 & 27.0 & 1.38 & 1.28 & +0.10 \\
70 & 18.5 & 1.25 & 1.18 & +0.07 \\
80 & 11.0 & 0.82 & 1.10 & -0.28 \\
\hline
\end{tabular}

(B) In Water-AN Mixture

\begin{tabular}{r|r|r|r|r}
\hline 0 & 78.5 & 2.32 & 2.32 & 0 \\
10 & 76.0 & 2.25 & 2.20 & +0.05 \\
20 & 72.5 & 2.20 & 2.11 & +0.09 \\
30 & 69.0 & 2.23 & 2.08 & +0.15 \\
40 & 64.5 & 2.30 & 2.04 & +0.26 \\
50 & 60.0 & 2.38 & 2.08 & +0.30 \\
60 & 54.5 & 2.50 & 2.12 & +0.38 \\
70 & 49.0 & 2.68 & 2.14 & +0.54 \\
80 & 44.0 & 2.88 & 2.18 & +0.70 \\
\hline
\end{tabular}

(N.B.) $\Delta I_{d}=I_{d}$ (Calcd.) $-I_{d}$ (Obsd.)

Electrolytic solution : $0.5 \mathrm{mM} \mathrm{TlCIO}_{4}$ in $0.2 \mathrm{~N} \mathrm{LiClO}_{4}$ in water-org. solvent mixture.

*) Equation ( 8 ) in the original paper 


$$
I_{d}={ }^{\circ} D^{1 / 2}(1-\Delta)^{1 / 2} \mathrm{~K}_{d}
$$

where $\mathrm{K}_{d}$ is a constant containing the constants of Ilkovic equation. If the variation of ${ }^{\circ} D$ with change of solvent composition obeys Stokes' low, the above equation leads to

$$
I_{d}=(1-\Delta)^{1 / 2} \eta^{-1 / 2} \mathrm{~K}
$$

where $\mathrm{K}$ is a constant containing $\mathrm{K}_{d}$ and ${ }^{\circ} D$ in pure aqueous solution. Then the relative diffusion current in any water-organic solvent mixture can be calculated by equation (5).

In Table I is given the comparison of the observed diffusion currents and the calculated values by equation (5) for $\mathrm{TlClO}_{4}$ as a depolarizing salt which hold the condition of $\left|Z_{1}\right|=\left|Z_{2}\right|=1$ as a simple example. The constant $\mathrm{K}$ was evaluated from the observed value of $I_{d}$ in the pure aqueous solution. (A) shows the data in water-dioxane solution and (B) in water-AN solution. Dielectric constants $\varepsilon$ of water-dioxane mixture were estimated from the values of Kraus et al. ${ }^{4)}$ and those of water-AN mixture from Strehlow et al. ${ }^{5)}$ As dielectric constants of water-DMF mixtures were not available in literature, the comparison was not made for this solution.

The observed values are in fair agreement with the calculated values up to $50 \%$ dioxane content in water-dioxane solution, but for water-AN system the deviation between both values already occurs at $20 \%$ AN content. The deviation becomes larger at high solvent content in both systems regardless of dielectric constant.

From these results some factors other than dielectric constant and viscosity should be considered to be also operative in the solution of high content of the organic solvent, even if Robinson-Stokes equation and Stokes' low are approximately held.*) Among the factors solvation and ion association may be the main factors that excert a marked effect on the diffusion current. Although a detailed discussion can not be made in the present time because of ambiguity on the structure of water-organic solvent mixture, a possible explanation may be as follows; In water-dioxane mixtures having a low dielectric constant, the lowering of diffusion coefficient in high dioxane content may be due to marked formation of associated ions, although there is little posibility of solvation because of extremely small dipolemoment $(\mu=0.45 \mathrm{D})$ of dioxane molecule. On the other hand, in water-AN mixtures having a larger dielectric constant, solvation may be predominant because of a larger dipolemoment $(\mu=3.37 \mathrm{D})$ of AN molecule. Hence, the size of diffusing particle may vary by selective solvation with varying content of organic solvent to lead a change in magnitude of the diffusion current.

\section{On the half-wave potential}

The standard electrode potentials of $\mathrm{Rb} / \mathrm{Rb}^{+}$system $^{6)}$, ferrocene system, cobaltocene system $^{7)}$ and others ${ }^{8)}$ have been proposed as a reference potential to relate the electrode potentials in various organic solvents to each other. In the present work, in order to compare the half-wave potentials in various water-organic solvent mixtures, the half-wave potential of ferrocene and that of cobalticinium ion were employed as reference potentials.

The half-wave potential for oxidation wave of ferrocene (designated as $E_{1 / 2}(\mathrm{Fe})$ ) and that for reduction wave of cobalticinium ion (designated as $E_{1 / 2}(\mathrm{Co})$ ) against the aqueous saturated calomel electrode $(\operatorname{SCE}(\mathrm{aq}))$ in the water-organic solvent mixtures are given in Table II. In these potentials, of course, the liquid junction potentials

*) In the present work 0.1 to $0.2 N$ supporting electrolyte were used, but it is said that the concentration for $1: 1$ electrolyte acceptable in equation of Robinson-Stokes is less than $0.1 N$. 
between $\operatorname{SCE}(\mathrm{aq})$ and the mixture are included. It is seen in Table II that the apparent half-wave potentials referred to $\operatorname{SCE}(\mathrm{aq})$ are shifted to more positive potential as the content of organic solvent is increased. If the view of Strehlow et al. ${ }^{7)}$ is valid that the standard potentials of the ferrocene and cobaltocene systems remain constant irrespective of the nature and content of solvent in mixture, it is concluded that the change of half-wave potential in the mixture comes from the change of liquid junction potential. Hence, approximate value of the change of liquid junction potential may be evaluated by the potential change.

The difference between $E_{1 / 2}(\mathrm{Fe})$ and $E_{1 / 2}(\mathrm{Co}), \Delta E$, in Table II remains constant at about $1.32 \mathrm{~V}$ irrespective of the nature and concentration of the organic solvent and this value is in approximate agreement with the difference between the standard potentials of ferrocene and cobaltocene systems in water, AN, methanol and formamide

Table II. $\boldsymbol{E}_{1 / 2}$ 's of Ferrocene and Cobalticinium Ion in Water-Organic Solvent Mixtures (in Volt vs. aqueous S.C.E.)

\begin{tabular}{c|c|c|c|c|c|c|c|c|c}
\hline Org. Solvent & \multicolumn{3}{|c|}{ Dioxane } & \multicolumn{3}{c|}{ DMF } & \multicolumn{3}{c}{ AN } \\
\cline { 1 - 7 }$\%$ in Vol. & $E_{1 / 2}(\mathrm{Fe})$ & $E_{1 / 2}(\mathrm{Co})$ & $\Delta E$ & $E_{1 / 2}(\mathrm{Fe})$ & $E_{1 / 2}(\mathrm{Co})$ & $\Delta E$ & $E_{1 / 2}(\mathrm{Fe})$ & $E_{1 / 2}(\mathrm{Co})$ & $\Delta E$ \\
\hline 0 & & $-1.20_{4}$ & & & $-1.20_{4}$ & & & $-1.20_{4}$ & \\
10 & $+0.14_{5}$ & $-1.19_{0}$ & $1.33_{5}$ & $+0.15_{5}$ & $-1.16_{0}$ & $1.31_{5}$ & $+0.13_{4}$ & $-1.19_{0}$ & $1.33_{3}$ \\
20 & $+0.16_{5}$ & $-1.16_{9}$ & $1.33_{4}$ & $+0.17_{0}$ & $-1.15_{3}$ & $1.32_{3}$ & $+0.15_{0}$ & $-1.17_{2}$ & $1.32_{2}$ \\
30 & $+0.17_{0}$ & $-1.14_{5}$ & $1.31_{5}$ & $+0.18_{5}$ & $-1.13_{1}$ & $1.31_{6}$ & $+0.17_{0}$ & $-1.14_{9}$ & $1.31_{8}$ \\
40 & $+0.20_{6}$ & $-1.11_{0}$ & $1.31_{5}$ & $+0.19_{0}$ & $-1.11_{0}$ & $1.30_{0}$ & $+0.18_{9}$ & $-1.12_{7}$ & $1.31_{5}$ \\
50 & $+0.21_{5}$ & $-1.08_{2}$ & $1.29_{7}$ & $+0.20_{5}$ & $-1.08_{5}$ & $1.29_{0}$ & $+0.20_{3}$ & $-1.10_{2}$ & $1.30_{5}$ \\
60 & $+0.25_{5}$ & $-1.04_{0}$ & $1.29_{5}$ & & $-1.05_{7}$ & & $+0.21_{4}$ & $-1.08_{6}$ & $1.30_{5}$ \\
70 & & $-1.00_{0}$ & & & $-1.03_{6}$ & & $+0.23_{0}$ & $-1.07_{0}$ & $1.30_{0}$ \\
80 & & $-0.97_{0}$ & & & $-0.99_{5}$ & & $+0.24_{6}$ & $-1.04_{8}$ & $1.29_{4}$ \\
\hline
\end{tabular}

$\boldsymbol{E}_{1 / 2}(\mathrm{Fe}), \boldsymbol{E}_{1 / 2}(\mathrm{Co})$ : Half-wave potentials of Ferrocene and Cobalticinium ion, resp. $\Delta E: E_{1 / 2}(\mathrm{Fe})-E_{1 / 2}(\mathrm{Co})$ in Volt.

Electrolytic solution : $0.5 \mathrm{~m} M \mathrm{Fe}\left(\mathrm{C}_{5} \mathrm{H}_{5}\right)_{2}$ in $0.2 N \mathrm{LiClO}_{4}$

$0.4 \mathrm{mM} \mathrm{Co}\left(\mathrm{C}_{5} \mathrm{H}_{5}\right)_{2}$ in $0.1 \mathrm{~N} \mathrm{NaClO}_{4}+$ Buffer soln. $(\mathrm{pH}=5)$.

Table III. Half-Wave Potentials of $\mathrm{Cd}(\mathrm{II})$ and $\mathrm{Tl}(\mathrm{I})$ Ion in Water-AN Mixtures

\begin{tabular}{|c|c|c|c|c|c|c|}
\hline \multirow[b]{2}{*}{$\begin{array}{c}\% \\
\text { in } \\
\text { Volume }\end{array}$} & \multicolumn{3}{|c|}{$E_{1 / 2}$ of Cd (II) Volt. vs. aq. S.G.E. } & \multicolumn{3}{|c|}{$E_{1 / 2}$ of T1 (I) Volt vs. aq. S.C.E. } \\
\hline & $\begin{array}{c}\text { Measured from } \\
E_{1 / 2}(\mathrm{Fe}) \text {. No } \\
\text { liq junction } \\
\text { potl. (A) }\end{array}$ & $\begin{array}{l}\text { Corrected } \\
\text { for liquid } \\
\text { junction potl. } \\
\text { (B) }\end{array}$ & $\begin{array}{c}\text { difference } \\
\text { (C) }\end{array}$ & $\begin{array}{l}\text { Measured from } \\
E_{1 / 2}(\mathrm{Fe}) \text {. No } \\
\text { liq. junction } \\
\text { potl. (A) }\end{array}$ & $\begin{array}{l}\text { Corrected } \\
\text { for liquid } \\
\text { junction potl. } \\
\text { (B) }\end{array}$ & $\begin{array}{c}\text { difference } \\
\text { (C) }\end{array}$ \\
\hline 10 & -0.583 & -0.570 & -0.013 & -0.445 & -0.441 & -0.004 \\
\hline 20 & -0.615 & -0.588 & -0.027 & -0.461 & -0.464 & +0.003 \\
\hline 30 & -0.636 & -0.613 & -0.023 & -0.482 & -0.481 & -0.001 \\
\hline 40 & -0.643 & -0.633 & -0.010 & -0.494 & -0.501 & +0.007 \\
\hline 50 & -0.647 & -0.650 & +0.003 & -0.514 & -0.516 & +0.002 \\
\hline 60 & -0.653 & -0.651 & -0.002 & -0.520 & -0.514 & -0.006 \\
\hline 70 & -0.660 & -0.658 & -0.002 & -0.526 & -0.521 & -0.005 \\
\hline 80 & -0.664 & -0.658 & -0.008 & -0.517 & -0.522 & +0.005 \\
\hline
\end{tabular}

Electrolytic soln. : $0.5 \mathrm{mM} \mathrm{Cd}\left(\mathrm{ClO}_{4}\right)_{2}$ or $0.5 \mathrm{~m} M \mathrm{TlNO}_{3}$, and $0.5 \mathrm{mMFe}\left(\mathrm{G}_{5} \mathrm{H}_{5}\right)_{2}$ in water-organic solvent mixture containing $0.2 \mathrm{~N} \mathrm{LiClO}_{4}$. 
observed by Strehlow et al. Therefore, $E_{1 / 2}(\mathrm{Fe})$ and $E_{1 / 2}(\mathrm{Co})$ may be regarded also as a constant within the precision of polarographic measurement in all the mixtures, i.e., the both potentials may be used as a reference potential.

The half-wave potentials of $\mathrm{Tl}(\mathrm{I})$ and $\mathrm{Cd}(\mathrm{II})$ in water-AN mixtures are listed in Table III, in which the potentials are measured independently against $E_{1 / 2}(\mathrm{Fe})$ and $E_{1 / 2}(\mathrm{Co})$ as the reference potential and then corrected for $\operatorname{SGE}(\mathrm{aq})$. The half-wave potential in column $\mathrm{A}$ in the Table was obtained by the following procedure. The polarogram was recorded with the water-organic solvent mixture containing both the depolarizing ion and ferrocene against $\operatorname{SCE}(\mathrm{aq})$ as a counter electrode. Then, the potential difference between the half-wave potential of the ion and that of coexisting ferrocene was measured and from the potential difference the half-wave potential of the ion was evaluated by correcting the potential to $\operatorname{SCE}(\mathrm{aq})$ assuming $E_{1 / 2}(\mathrm{Fe})$ to be constant $(+0.134 \mathrm{~V}$ vs $\mathrm{SCE}(\mathrm{aq})$ at $10 \% \mathrm{AN}$ solution). Hence, the value does not include the liquid junction potential. The value in Column B was obtained by measuring the half-wave potential of the ion alone in the same basal solution in which $E_{1 / 2}$ (Co) was measured (Table II), and correcting the liquid junction potential evaluated from the shift of $E_{1 / 2}(\mathrm{Co})$ in Table II. Column $\mathrm{G}$ indicates the difference of potentials in Column A and B. It is seen in Table III that the values obtained by both methods coincide with each other within the error of $10 \mathrm{mV}$, especially taking into account the experimental instability of liquid junction potential.

Since the measurement of the precise half-wave potential of ferrocene in pure aqueous solution is difficult due to its low solubility in water, the half-wave potentials of $\mathrm{Tl}(\mathrm{I}), \mathrm{Cd}(\mathrm{II})$, and $\mathrm{Pb}(\mathrm{II})$ in the mixtures of the organic solvents and water were evaluated by the method of correcting liquid junction potential. The dependences of the half-wave potentials on the content of the organic solvents are shown in Figs. 5-7. In water-dioxane system the half-wave potentials of all the ions shift to more negative potential as dioxane content is increased, but the extent of shift is the smallest for $\mathrm{Tl}(\mathrm{I})$. Similar tendency was also observed in water-DMF system. In water-AN system the extent of shift is smaller than those in the other systems and particularly that for $\mathrm{Tl}(\mathrm{I})$ is small and no shift is observed in the solution of 50 to $80 \%$ of $\mathrm{AN}$.

According to Born's theory, in which the change of free energy with transfer of an

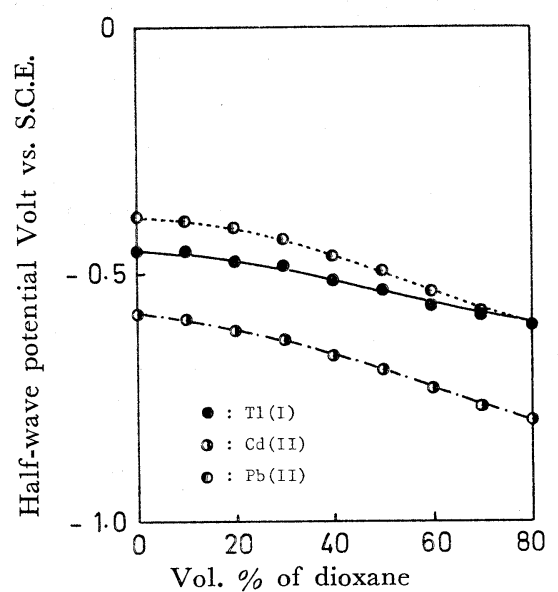

Fig. 5. Variation of half-wave potential with content of dioxane

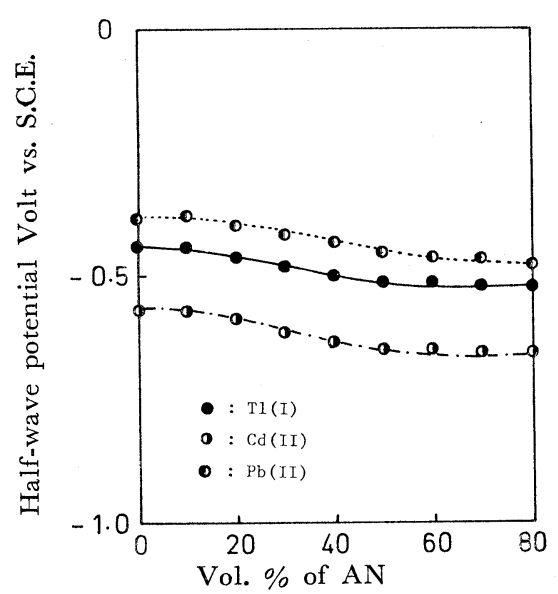

Fig. 6. Variation of half-wave potential with content of $\mathrm{AN}$ 
ion from a solution to another having a different dielectric constant is assumed to be caused only by the change of electrostatic force, the change of transfer free energy $\Delta G$ is expressed by the familiar equation

$$
\Delta G=-\frac{\mathrm{NZ}^{2} \mathrm{e}^{2}}{2 r} \cdot\left(-\frac{1}{\varepsilon_{2}}-\frac{1}{\varepsilon_{1}}\right)
$$

where $r$, and $\varepsilon$ mean the effective radius of the ion and the dielectric constant of the solution, respectively.

Therefore, the smaller the dielectric constant, or the larger the content of organic solvent in a mixture, the half-wave potential should be shifted to the more positive potential ${ }^{10)}$. But the observed half-wave potentials are shifted to more negative potential with increasing content of the

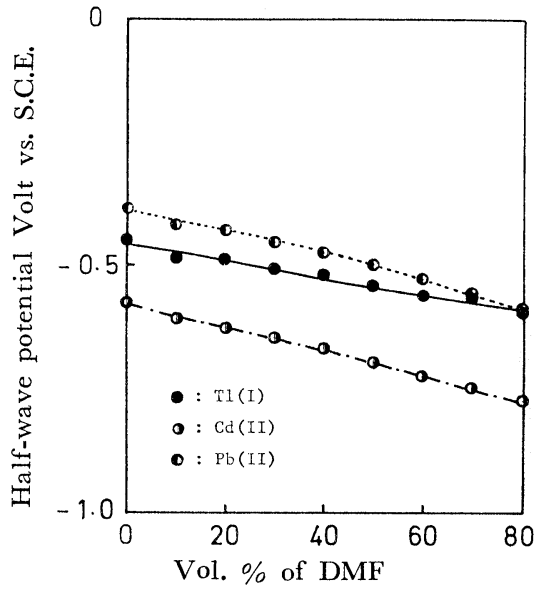

Fig. 7. Variation of half-wave potential with content of DMF organic solvent, and the extent of shift is greater for divalent ion than for univalent ion.

Takahashi $^{11)}$ investigated the change of half-wave potential of $\mathrm{Tl}(\mathrm{I})$ and $\mathrm{Cd}(\mathrm{II})$ in water-AN mixture and found a linear relationship between reciprocal of the dielectric constant of the mixture and the half-wave potential corrected for diffusion coefficient and ionic interaction, and concluded that these ions do neither react chemically with solvent molecules nor form ion-pairs with coexisting ions. However, a linear relationship could not be found when the similar procedure to that of Takahashi was made with the values obtained in the present work.

A reason for this discrepancy may be a difference of concentration of the supporting electrolyte in both works. The supporting electrolyte of $0.04 \mathrm{~N} \mathrm{KNO}_{3}$ was used in the work of Takahashi, whereas in the present work 0.1 to $0.2 \mathrm{~N}$ alkaliperchlorates were used. The validity of Debye-Huckel equation to claculate activity coefficient in such a high concentration as $0.1 N$ is questionable. Moreover, it is reasonable to assume that ion-association may be significant in such a high concentration. The fact that the greater the valency of ion, the larger the shift of potential as shown in Figs. 5-7 suggests the formation of ion-pairs and complexes.

\section{Acknowledgement}

The authors wish to express their thanks to Prof. Rejii Takahashi, of Ritsumeikan University, for his advice and discussion.

\section{References}

1) G. Ebert \& J. Mendorff : Ber. Bunsenges. Physik. Chem., 74, 1071 (1970).

2) I. Tachi \& R. Takahashi : Collection Czechslov. Chem. Communs., 25, 3111 (1960).

3) R.A. Robinson \& R.H. Stokes : J. Amer. Chem. Soc., 76, 1991 (1954).

4) G. A. Kraus \& R.M. Fuoss : ibid., 55, 21 (1933).

5) H. Strehlow \& H. M. Koepp : Z. Elektrochem., 62, 3731 (1958).

6) V.A. Pleskov : J. Phys. Chem. USSR, 22, 351 (1948).

7) H.M. Koepp, H. Wendt \& H. Strehlow : Z. Elektrochem., 64, 483 (1960). 
8) G. Schöber \& V. Gutmann : Monatsch. Chem., 90, 897 (1959). I.V. Nelson \& R.T. Iwamoto : Anal. Chem., 33, 1795 (1960) ; 35, 867 (1963).

9) M. Born : Z. Physik., 1, 45 (1920).

10) For example, see R. Takahashi : Talanta, 12, 1291 (1965). I. M. Kolthoff : J. Polarog. Soc., 10, 22 (1965).

11) R. Takahasi : Rev. Polarog. (Kyoto), 9, 116 (1961) ; 11, 190 (1963).

\section{水一有機混合溶媒中の金属イオンのポーラログラフ的挙動}

\section{鈴木 信, 澤田 恵夫, 安田孝治朗}

(近畿大学理工学部化学教室)

水一有機混合溶媒系にわいて, 溶媒組成による粘度, ポーラログラフ波高および半波電位を各有機溶媒につ いて測定した，拡散電流が粘度変化だけにより変化す るものと仮定して実測波高を実測粘度から計算した波 高と比較すると，ジオキサンの場合，低い有機溶媒含 量では両者はかなりよく一致するが，DMF，アセトニ トリルの場合は偏差が見られる。一方高い有機溶媒含 量では，ジオキサンの場合偏差が極端に大きくなる が，DMF，アセトニトリルの場合，それ以上大きくな っててない，従って両者の偏差は有機溶媒の性質に関
係しているてとが認められる。乙れらの原因として， ジオキサンの場合，イオン会合が，そして DMF，ア セトニトリルの場合，選択的溶媒和が考学引れる，1 洒の $\mathrm{Tl}^{+}$イオンについては更に 緩和効果の補正をし た所よりよい一致が得られた。

半波電位についてはフェロセンおよびコバルトセン によって液間電位を補正して溶媒組成との関係を調べ たが，ボーンの式に従わず，イオン会合等が影響して いるものと思われる。 